\title{
Van wie zegt de profeet dit? \\ Een een-voudige vraag en een meer- voudig antwoord
}

\author{
Rein Bos (Kampen, Nederland) \\ Gastonderzoeker: Departement Praktiese Teologie \\ Universiteit van Pretoria
}

\begin{abstract}
Of whom does the prophet say this?

A single question and a multifaceted answer

Theologians seeking to preach Old Testament texts meaningful way in Christian congregations face a great challenge. On the one hand, very little has been written in homiletical textbooks about hermeneutical problems facing those who wish to read the Old Testament from the perspective of Christ's life and death. On the other hand, advances in biblical criticism seemed to have made any such attempt problematic to begin with. In this article, the author attempts to provide a practical-theological contribution to this hermeneutical challenge by reconsidering the heuristic value of mediaeval fourfold interpretation of scriptural passages. By focussing on the servant song of deutero-Isaiah (53) in light of its reinterpretation in Acts 8, this paper aims to provide some suggestions on how Christological interpretation of the Old Testament can be done in a way that takes the original context seriously and is able to read the text from a Christian perspective without the one reading infringing on the other.
\end{abstract}

\section{VERSTAAT GIJ WAT GIJ LEEST?}

\subsection{Kennen en herkennen}

$\mathrm{Na}$ een bedevaart aan Jeruzalem is een hooggeplaatste Ethiopische eunuch weer op de terugweg naar zijn land (Hand 8:26-40). Hij leest de profeet Jesaja in zijn koets. Filippus treedt nader en stelt een vraag die een gevleugelde

\footnotetext{
* Dr Rein Bos (Kampen, Nederland) is als gastonderzoeker betrokken bij het HomLit project van prof dr C J A Vos in de afdeling Praktische Theologie van de theologische faculteit van de Universiteit van Pretoria.
} 


\section{Van wie zegt de profeet dit?}

uitdrukking is geworden: "Verstaat gij wat gij leest?" (Ginooskeis ha anaginooskeis). Hij herkent de lettertekens wel maar hij kent de betekenis (nog) niet, hij kan de buitenkant van de letters wel ontcijferen met een literaire grammatica maar hij heeft geen sleutel die hem toegang verschaft tot de betekenis van de binnenkant van de tekst.

De eunuch citeert enkele verzen uit Jesaja 53 waar gesproken wordt over het lijden van de knecht des HEREN. De Ethiopische ambtenaar stelt vervolgens de vraag die ons tot op de dag van vandaag intrigeert: "Van wie zegt de profeet dit? Van zichzelf of van iemand anders?". De beantwoording van deze vraag in de praktijk van de christelijke prediking oscilleert tussen twee uitersten. Aan de ene kant is er prediking die een onbekommerde, directe en ook exclusieve relatie legt tussen de knecht des HEREN en Jezus Christus. Deze uitleg wekt de indruk dat Filippus als antwoord heeft gegeven "Dit zegt de profeet inderdaad van iemand anders, namelijk van Jezus Christus". Deze uitleg heeft vele eeuwen geklonken, in allerlei variaties en gestalten, tot op de dag van vandaag.

De resultaten van het historisch- en literair-kritisch onderzoek hebben veel vragen geplaatst bij deze onbekommerde en directe relatie tussen de knecht des HEREN in Deutero-jesaja en Jezus Christus. Allerlei historische, literaire en theologische tegenwerpingen kwamen op tafel. "Wer einmal vom Baum der historischen Erkenntnis gegessen hat, dem gehen die Augen auf, und er muß erkennen, wie nackt er ist. Er ist aus dem christologischen Paradies vertrieben und muß sich mit vielleicht spärlichen historisch-kritischen Fellen bedecken. Der Weg ins Paradies ist inm aber für ewig verschlossen" (Oeming 1985:87).

De herontdekking van de joodse traditie na de Tweede Wereldoorlog heeft een extra dimensie aan deze verlegenheid toegevoegd. Toen het drama dat we samenvatten in de naam Auschwitz tot de christelijke kerk begon door te dringen, bleef dat niet zonder ingrijpende gevolgen voor theologie en prediking. Er waren stemmen die er daarom voor pleitten om het kerkelijk spreken te zuiveren van exclusieve christelijke annexatie en absorptie van de boeken van Mozes en de profeten.

\subsection{Dilemma}

Als gevolg van deze verlegenheid staan predikanten voor een dilemma. Aan de ene kant zijn zij wetenschappelijk geschoold, hebben kennis genomen van moderne theologische paradigmata, zijn getraind in hedendaagse exegetische methoden en weten van de vragen die resoneren in de post-holocaust context. Anderzijds weten zij zich geroepen om getuige van Christus te zijn. Zij zijn voorgangers in de gemeente die leeft van "de dingen aangaande 
Jezus van Nazaret" (Luc 24:19) en kunnen zich om die reden niet onttrekken aan bezinning op de christologische vragen. De kerk verstaat zichzelf immers als een gemeenschap van gelovigen die door Israëls God zijn geroepen uit alle volkeren om Hem te vertrouwen en zijn Koninkrijk te dienen. De naam van Jezus en de belijdenis aangaande Christus spelen daarbij een centrale rol, zowel in de gemeenschap van de kerk als voor de individuele gelovige. De christologie ligt dan ook in het hart van de kerk en drukt een stempel op alles wat zij verder zegt en doet. Zo poneert Karl Barth niet ten onrecht: "Sage mir, wie es mit deiner Christologie steht und ich sage dir, wer du bist" (Barth 1980:76).

In de praktijk lijken voorgangers te moeten laveren tussen (kerkelijke) Scylla en (wetenschappelijke) Charybdis. Moeten zij gehoor geven aan hun wetenschappelijke training (en de christologische component laten liggen) of moeten ze kiezen voor het getuigenis aangaande Christus (en hun theologische training negeren)?

\section{PREDIKING EN HET HERMENEUTISCH PROBLEEM}

\subsection{Hermeneutisch probleem in de homiletiek}

De vraag van de Ethiopische ambtenaar staat in het bredere perspectief van de verhouding tussen Oude en Nieuwe Testament. De praktijk van de preekvoorbereiding confronteert de prediker steeds opnieuw met de hermeneutische vragen naar de interpretatie van het Oude Testament in een christelijke context. We kunnen zelfs zeggen dat de prediking de plek is waar de vraag naar de verhouding van Oude en Nieuwe Testament in eerste instantie wordt opgeroepen. Er is immers een "unauflösliche Wechselbeziehung zwischen hermeneutische Problemen und homiletischen Fragen" (Rössler 1961:153-154). Het gaat dan om het moment in de preekvoorbereiding waarop de vraag beantwoord moet worden: Hoe leg je in een concrete preek op een verantwoorde manier verbindingen tussen een oudtestamentische tekst en Jezus Christus? En moeten in een preek naar aanleiding van een oudtestamentische tekst het Nieuwe Testament en Jezus Christus wel ter sprake komen om een christelijke preek genoemd te kunnen worden?

De antwoorden die in de loop der geschiedenis op deze vragen zijn gegeven, kregen vorm in hermeneutische theorieën met korte aanduidingen als karakterisering: belofte en vervulling, heilsgeschiedenis, schaduw en werkelijkheid, typologie, profetie en vervulling, structuuranalogie, het tegoed van het Oude Testament, antithese, traditie-historie om enkele voorbeelden te noemen. Deze theorieën zijn evenzoveel sleutels om niet alleen de literaire 


\section{Van wie zegt de profeet dit?}

buitenkant te verstaan maar ook en vooral toegang te krijgen tot de kergumatische betekenis van de binnenkant van de tekst.

$\mathrm{Nu}$ is het opvallend dat het in de homiletische handboeken ontbreekt aan een vertaling van de hermeneutische theorieën naar de praktijk van de prediking. De gangbare handboeken laten de prediker op dit punt dan ook feitelijk met lege handen staan. In klassieke homiletieken wordt deze materie niet of nauwelijks zelfstandig aan de orde gesteld (Hoekstra 1926; Davis 1958). Ook in meer recente homiletieken komt deze materie in het geheel niet (Buttrick 1987; Long 1989; Zerfaß 1992; Theißen 1994; Allen 1998) of slechts in de marge aan de orde (Schütz 1981:81-87; Bohren 1986:119-121; Hirschler 1988:198-212; Dingemans 1991:97-100; K Müller 1994:69-73; H M Müller 1996:222-227; Engemann 2002:282-287). Vos ruimt wel een aparte paragraaf in voor deze materie maar deze is geschreven door de oudtestamenticus Prinsloo (Vos 1995:374-392). Geen van de handboeken biedt een praktische operationalisering van de hermeneutische theorieën. Het lijkt er op dat elke predikant op dit punt een eigen hermeneutische sleutel moet construeren.

\subsection{Opzet van dit artikel}

De contemporaine christelijke prediking naar aanleiding van oudtestamentische teksten staat steeds opnieuw voor de uitdaging antwoord te geven op de vraag van de Ethiopische ambtenaar: "Van wie zegt de profeet dit?". Op welke wijze kunnen we (s)preken over de identiteit van de gestalte van de knecht des HEREN waar we van horen in vier liederen in Deutero-jesaja? Blenkinsopp stelt "that it is much easier to formulate questions - over and above the question about the Servant's identity that the Sudanese official in Acts 8:34 posed - than to provide answers" (Blenkinsopp 2000:76). Het onderzoek aan deze vier gedichten heeft een enorme hoeveelheid literatuur opgeleverd. "The bibliography on this topic is enormous, indicating the great interest in the subject and the lack of agreement on it." (Watts 1987:227).

Dit artikel is niet bedoeld om een exegetische bijdrage toe te voegen aan deze bibliografie. Ik wil wel vanuit een praktische theologische achtergrond kijken hoe deze liederen in de praktijk van de prediking van de christelijke kerk (kunnen) functioneren en een homiletisch antwoord formuleren op de vraag van de Ethiopische ambtenaar. Daarmee biedt dit artikel zowel een samenvatting als een illustratie van het hermeneutische model dat ik heb ontwikkeld ten bate van de prediking naar aanleiding van oudtestamentische teksten. Dat concept alsmede de genese heb ik breder beschreven in Wij hebben gehoord dat God met $u$ is (Bos 2004).

In het vervolg van dit artikel teken ik eerst de wijze waarop de concrete praktijk der prediking de liederen aangaande de knecht des HEREN behandelt 
en geef een evaluatie van de theologische implicaties van deze praxis (§ 3$)$. Voor de ontwikkeling van een alternatief ga ik te rade bij de wijze waarop apostelen en evangelisten de woorden uit de vier liederen aangaande de knecht des HEREN citeren (§ 4). Zij bieden ingrediënten voor het ontwerp van een contemporaine hermeneutische grammatica $(\S 5)$.

\section{ILLUSTRATIE VAN DE PREEKPRAKTIJK}

De wijze waarop klassieke hermeneutische modellen functioneren in de praktijk der prediking kan goed geïllustreerd worden aan de hand van een fragment uit materiaal voor de preekvoorbereiding en een preekfragment naar aanleiding van Jesaja 42:1-7, het eerste lied aangaande de knecht des HEREN.

\subsection{Opzet van preken naar aanleiding van oudtestamentische teksten}

Wanneer Jesaja 42:1-7 in de liturgie klinkt, ligt het voor de hand dat kerkgangers - bewust of onbewust - woorden, beelden en uitdrukkingen in verband brengen met Jezus Christus. Bij "mijn knecht” zal gedacht worden aan de dienstbaarheid van Jezus. Bij "mijn uitverkorene, in wie Ik een welbehagen heb" zal mogelijk een link worden gelegd met woorden die klinken bij de doop van Jezus in de Jordaan. In de evangeliën is ook een echo te horen van de woorden "niet schreeuwen". Jezus maakte immers geen ophef van de wonderen die Hij verrichtte. Hij verbood zijn leerlingen zelfs om daar ruchtbaarheid aan te geven. Wanneer van de knecht wordt gezegd dat hij het geknakte riet niet zal verbreken en de kwijnende vlaspit niet zal uitdoven, kan gedacht worden aan Jezus" liefde voor de zwakken. Deze verbanden geven aanleiding om dit gedeelte te zien als een profetie en zelfs een voorspelling aangaande Jezus. In het verlengde van deze "gemeentetheologie" zijn in concrete preken op het hermeneutische spoor twee stations te onderscheiden. Op dat eerste station besteden preken aandacht aan de knecht in de context van de ballingschap.

Dit gedeelte vertelt dat er onder de ballingen in Babel iemand geweest is, die aan Israël is voorgesteld als de knecht des HEREN. lemand die zelf in het lot van de ballingen deelde, maar die toch anders was. lemand die, begiftigd met Gods geest, oog had voor Gods trouw en inzicht in Gods weg in de geschiedenis. lemand, die aan de ballingen weer nieuwe hoop gaf door hun Gods oordelen te verkondigen, oordelen die een wending brengen in het wereldgebeuren. lemand die hen influistert dat hun geknakte bestaan voor God betekenis heeft.

De taak van de knecht bestaat bij uitnemendheid hierin, dat hij het geknakte riet van Israël weer herstelt zodat Israël als geheel haar taak van knecht Gods weer op zich kan nemen. Het is de 


\section{Van wie zegt de profeet dit?}

roeping van de ene knecht om de kwijnende vlaspit van het volk weer te vitaliseren zodat het volk als geheel de taak van licht der natiën weer op zich kan nemen zodat blinden de ogen worden geopend, gevangenen uit de kerker worden geleid en wie in duisternis gezeten zijn uit de gevangenis worden geleid.

(De Jong 1984:239)

Deze knecht - met kleine letter $\mathrm{k}$ - heeft licht verspreidt met zijn prediking onder ontredderde ballingen. Op een tweede station maken preken vervolgens een overstap naar Jezus als de Knecht - met hoofdletter K. Die overstap kan geïllustreerd worden aan de hand van het volgende preekfragment naar aanleiding van dit gedeelte. Voorafgaand aan dit citaat heeft de preek verwezen naar de context van de ballingschap. En vervolgens "lijkt die Knecht wel heel erg op Jezus".

En wie kan er hier bedoeld zijn? Daarover is al heel veel geschreven. Ik ga daar nu niet op in. Maar één ding is heel duidelijk: in deze knecht wendt God zelf zich heel direct tot die vertwijfelde joodse ballingen. Hij bemoeit zich met hen, begeeft zich onder hen. Genadig en barmhartig en vol compassie. De Here God zelf.

Eén ding is heel duidelijk: die Knecht van God lijkt wel heel erg op Jezus. In Jezus gaan deze woorden volkomen in vervulling (zie Mat 12:18-21). Niemand die zo dicht staat bij God. Niemand in wie God zo direct zelf zich onder ons liet zien als in Jezus Christus.

God stelt Hem hier al voor. Hier in het donker, zeg maar: het graf van de ballingschap. God zegt: Jullie zijn niet vergeten. Jullie zijn niet alleen. Zie mijn Knecht. Daar, daar komt Hij al. Zie op Hem. Dat is: zet je hoop op Hem.

Wat komt Hij doen? Wel, Hij komt recht doen. Recht, eindelijk. Recht in de zin van: zeggen wat recht is volgens God en dat ook doorzetten, en vorm geven, verwezenlijken. Dat zal mijn Knecht doen, zegt God. Dat zal zijn missie wezen.

(De Jong 1995:3)

Aan de hand van deze specifieke illustraties kunnen enkele algemene karakteristieken van de klassieke hermeneutische modellen (typologie, heilshistorisch, allegorie, belofte en vervulling) worden aangewezen. Ik vat die samen onder drie noemers: Christus, Israël en de hoorders.

\subsection{Christus}

In de gegeven illustratie zegt de prediker dat Jezus komt om "eindelijk" recht te doen en dat recht door te zetten. Het woord "eindelijk" brengt de suggestie met 
zich mee dat er voor de komst van Jezus geen of onvoldoende sprake was van Gods recht en het doorzetten daarvan.

Uit mijn onderzoek blijkt dat preken die geborduurd zijn op het stramien van de klassieke hermeneutische modellen het eigenlijke heil voor de hoorders verkondigen op grond van de nieuwtestamentische Jezus (Bos 2004:117). Deze concepten hebben voor de verkondiging van Gods heil niet genoeg aan de woorden van Mozes en de profeten. Daarbij is de christologische component van de prediking doorgaans toegespitst op het geestelijk heil. Daarmee wordt het Nieuwe Testament feitelijk gezien als een beter, rijker, diepzinniger en vooral meer evangelisch boek dan het Oude Testament. Resultaat is dat het Oude Testament theologisch schuil gaat achter het Nieuwe Testament.

De gekozen opzet betekent vervolgens dat preken in hermeneutisch opzicht een exclusieve beweging naar voren maken in de geschiedenis, zowel binnen het Oude Testament als van Oude naar Nieuwe Testament. De behandeling van verschillende schakels in de keten van de knecht - Israël, profeet, Jezus - krijgt dan niet alleen een bepaalde volgorde in preken maar ook een rangorde: de laatste stap is de meest gezaghebbende. Jezus is dan de ware Knecht. In het preekfragment zegt de voorganger in die toonzetting "In Jezus gaan deze woorden volkomen in vervulling". In sommige gevallen werd daar expliciet aan toegevoegd of impliciet van uit gegaan, dat Israël deze rol heeft verspeeld omdat ze Jezus niet als Messias hebben aanvaard. Op deze wijze absorbeert het getuigenis aangaande Jezus de oudtestamentische tekst geheel.

Alle klassieke sleutels bewegen zich in de praktijk van de prediking op deze heilshistorische éénrichtingsweg. Tussen schepping en voleinding kent deze heilsgeschiedenis enkele markante en beslissende momenten, zogeheten kairoi. Die bijzondere momenten hebben steeds te maken met "progressieve reducering", dat wil zeggen een voortgaand proces van plaatsvervanging met een steeds kleiner aantal personen. God begint met de gehele mensheid (Gen 1-11). Als die Zijn heilsbedoeling niet effectueren, kiest God uit de mensheid één volk, te weten Israël. Nu is dat volk geroepen een licht te zijn voor alle volkeren. De zegen aan Abraham is bedoeld om zich uit te strekken over alle volkeren (Gen 12:1-3). Als Israël deze roeping niet waar kan maken en in ballingschap geraakt, gaat God verder met een "rest” (Jes 10:20-22; Jer 23:3). Wanneer die groep eenmaal uit de ballingschap weer in het beloofde land terug is, moet deze rest plaatsvervangend voor het volk optreden en doen waar het gehele volk niet toe in staat was. Als die rest daar ook niet in slaagt, kondigt God zijn Knecht aan (waaronder de liederen aangaande de knecht des HEREN in Deutero-jesaja). En zo doet God een laatste inzet met één mens, zijn Zoon 


\section{Van wie zegt de profeet dit?}

(Mar 12:6). Hij zal de wereld definitief de redding brengen die God al zo lang voor ogen stond.

Deze hermeneutische en theologische achtergrond is in de praktijk van de prediking tastbaar in de opbouw van de preken. Wanneer het station Christus eenmaal is gepasseerd, verdwijnt zowel inhoudelijk als voor wat betreft de opbouw van de prediking het Oude Testament achter de horizon.

\subsection{Israël}

De christologische verbinding tussen Oude en Nieuwe Testament in preken die gebruik maken van de klassieke hermeneutische sleutels, geschiedt vrijwel steeds in exclusieve zin. Dat wil zeggen dat er geen ruimte is voor een eigen zin en zeggingskracht van Mozes en de profeten voor contemporaine Joden. Het preekfragment zegt dat God zich wendt tot de Joden in de ballingschap. Alsof Gods bemoeienis met Joden en Israël daar opgehouden zou zijn! Daarmee staan de behandelde concepten aan het gevaar bloot om de Schrift aan Israël te onteigenen. De klassieke modellen gaan er - impliciet of expliciet - van uit dat de rol van Israël is uitgespeeld in Gods geschiedenis. De achterliggende gedachte is dat de bijzondere rol en roeping van Israël, sinds het Jezus heeft verworpen als de Messias, is overgegaan op de kerk. Israël, synagoge en Jodendom komen slechts aan de orde onder het voorteken van "toch", "hoewel" of "nochtans" (Büttner 2002:189).

\subsection{Hoorders}

Preken die gebruik maken van de klassieke sleutels blijven in de praktijk niet zelden steken in een beschrijving van binnen-bijbelse fenomenen. De betekenis van de tekst blijft als het ware resoneren tussen beide testamenten. De hoorders worden daardoor geen deelgenoot van het gebeuren tussen God en mens waar de tekst van getuigt maar blijven toeschouwer van een gebeuren tussen de oudtestamentische tekst en Christus (Gunneweg 1983a:159). De tekst raakt het bestaan van de hoorder niet omdat deze in de preek blijft "stuiteren" tussen Oude en Nieuwe Testament (Bos 2004:119-120).

Als gevolg van de heilshistorische éénrichtingsweg raken zowel aan de oudtestamentische "voorkant" als aan de post-paschale "achterkant" van die geschiedenis gestalten van de knecht buiten beeld. In die zin kan gezegd worden dat de directe zeggingskracht van het Oude Testament voor hedendaagse hoorders is opgehouden toen Jezus zei: "het is volbracht". Het Oude Testament is vanuit dat perspectief gestorven op Goede Vrijdag en het Nieuwe Testament opgestaan op de Paasmorgen. 


\subsection{Het Oude Testament als onvoltooide symfonie}

In de verschillende hermeneutische concepten is het Oude Testament "fast überall als Vorstufe zum Christusgeschehen und als Geschichte auf Christus hin und als von diesem Geschichtsziel her geheiligt” (Gunneweg 1977:154). Mozes en de profeten vormen een onvoltooide symfonie. De formele opbouw van dergelijke preken - beginnen met het Oude Testament en Jezus Christus aan het slot - versterkt het idee van een hiërarchische verhouding tussen beide testament. Het "Oude" van het Oude Testament betekent in deze gevallen inderdaad: verouderd en afgedaan. Enigszins scherp geformuleerd zou men kunnen zeggen dat - ondanks de bedoeling van het tegendeel - een dergelijke prediking Marcion alsnog gelijk geeft. De ideeën van deze ketter uit de oudheid steken niet alleen bedekt maar ook openlijk met enige regelmaat de kop op."Although the views of Marcion were condemned and have been generally rejected ever since ... the shadow cast by this second-century theologian still falls over Christians today" (Klein 1992:7).

\section{OP ZOEK NAAR EEN ALTERNATIEF}

\subsection{Binnen-bijbelse hermeneutiek}

Mijn zoektocht naar een eigen hermeneutisch model is begonnen met een praktisch-theologisch onderzoek naar de oudtestamentische citaten in het Nieuwe Testament. Ik had het vermoeden dat een dergelijk onderzoek nieuwe inzichten zou kunnen opleveren voor een homiletische praktijktheorie. Zo had $i k$, vanuit mijn eigen omgang met de Schrift, ontdekt dat niet alle oudtestamentische citaten in het Nieuwe Testament in een christologische context staan. Zo citeert Lucas bijvoorbeeld psalmen om na Pinksteren het opvullen van de lege plaats van Judas te beschrijven en te legitimeren (Ps 69:26; 109:8/Hand 10:6, 11). Dit gebruik kan als ecclesiologisch gekwalificeerd worden en in elk geval niet als christologisch. Daardoor ontstond beredeneerde aarzeling tegenover de bijbels-theologische fundering en rechtvaardiging van bestaande hermeneutische modellen die een exclusief christologisch gebruik veronderstellen. In de betreffende paragrafen werden alle teksten in één christologisch model geperst. Deze modellen fungeren als Procrustesbed die de diversiteit van de citaten teniet doet. We zouden ook kunnen zeggen dat dergelijke modellen zich met één en dezelfde christologische loper geforceerd toegang pogen te verschaffen tot de binnenkant van de tekst.

In het eigen bijbels-theologisch onderzoek gaat het me niet om een gedetailleerde studie naar de wijze waarop bijvoorbeeld Matteüs of Paulus met het Oude Testament omgaan. Het gaat evenmin om de vraag of de 


\section{Van wie zegt de profeet dit?}

apostelen en evangelisten gebruik hebben gemaakt van de Griekse of de Hebreeuwse versie van het Oude Testament. Het gaat me ook niet om de vraag van welke (Joodse of Griekse) hermeneutische sleutels zij gebruik hebben gemaakt. Deze vragen zijn wel van belang maar deze liggen in eerste instantie op het bord van andere disciplines. Ik doe dit onderzoek met een homiletische interesse. De achterliggende vooronderstelling is dat het zicht krijgen op de meerdimensionale binnen-bijbelse hermeneutische grammatica de homiletische reflectie en de praktijk van de prediking verder kan helpen in haar bezinning op preken naar aanleiding van het Oude Testament.

\subsection{Citaten in het Nieuwe Testament}

Wanneer we de citaten uit de liederen aangaande de knecht des HEREN in het Nieuwe Testament analyseren, dan is het geen verrassing daar een gebruik in een christologische context waar te nemen. Deze komen voor in zowel de beschrijving als in de duiding van het Christus-gebeuren. Zo gebruiken de evangelisten (doorgaans impliciet) deze liederen ter beschrijving van details en plot van de lijdensgeschiedenis. Zo kunnen we onder lezen over het zwijgen van Jezus (Mat 26:67 / Jes 53:7), het gerekend worden onder de misdadigers (Luc 22:37 / Jes 53:12), het onderworpen worden aan vernederingen (Mat 26:67 / Jes 50:5) en de rol van Jozef van Arimatea (Mat 27:57 / Jes 53:9). Het is daarbij overigens wel opvallend dat de evangeliën in de passiegeschiedenis nauwelijks verwijzingen hebben naar het vierde lied met een expliciet soteriologisch karakter. Het enige citaat in Matteüs uit het vierde lied (Mat 8:12-21) heeft betrekking op de genezings-verhalen en niet op het dragen van schuld en zonde.

We vinden ook aanhalingen uit de liederen aangaande de knecht des HEREN om de roeping van Jezus theologisch te duiden. Zo horen we bij zijn doop woorden en beelden uit het eerste lied (Mar 1:11 en parallellen).

\subsection{Niet-christologisch gebruik}

Naast dit expliciet christologische gebruik zijn er ook aanhalingen, echo's en citaten van de vier liederen uit Deutero-jesaja in een niet-christologische context waar te nemen. In de eerste plaats is daar een wijze van aanhalen die theologisch in engere zin genoemd kan noemen. Hebreen 4:12 gebruikt woorden en beelden uit Jesaja 49:2 om de werking van het woord Gods te beschrijven en theologisch te kwalificeren. Het Woord Gods wordt daar gepersonifieerd voorgesteld in de gestalte van een knecht (Grässer 1990:228).

Hoewel deze verwijzing wel duidelijk is, betreft het geen letterlijk citaat in engere zin. Daarnaast zijn er zijn wel expliciet ecclesiologisch georiënteerde citaten aan te wijzen. Zo wordt het missionaire optreden van Paulus en Barnabas in Handelingen 13:47 beschreven, geduid en 
gelegitimeerd met een beroep op Jesaja 42:6 en 49:6. Paulus en Barnabas citeren uit de liederen aangaande de knecht des HEREN als waren deze rechtstreeks tot hen gericht: "heeft ons opgedragen" (Van Eck 2003:299). Paulus en Barnabas hebben het appél in deze liederen als een persoonlijke oproep verstaan. "Men heeft in onze tekst ook wel aan de Messias gedacht ..., maar dat is toch gewrongen. Het gaat hier over de volgelingen van de Messias die de in Hem gekomen redding verkondigen en zo tot licht van de heidenen worden" (Lindijer 1979:38; vgl. Koole 1985:143).

In Romeinen 15:21 verbindt Paulus het getuigenis aangaande de knecht des HEREN (Jes 52:15) eveneens expliciet met zijn eigen zending naar de volkeren. "It should be noted that the one definite quotation in Paul"s epistles from the servant songs occurs in Romans but is used in a nonChristological way (Rom 15:21 = Is 52:15 LXX)" (Guthrie 1981:266). Eerder in de brief $(\operatorname{Rom} 1: 1,5)$ is ook al verwantschap te beluisteren met één van de liederen aangaande de knecht des HEREN (Jes 52:7). In Romeinen 10:16 is vergelijkbaar de echo te horen van Jesaja 53:1 (Dunn 1988:869). In Galaten 1:15 is de echo van Jesaja 49:1 te horen wanneer Paulus zijn bijzondere plaats in de voortgang van het evangelie beschrijft, legitimeert en duidt.

In latere delen van het Nieuwe Testament komen we nog een ander ecclesiologische toepassing van de liederen aangaande de knecht des HEREN tegen. Zowel in 2 Timoteüs 2:24-26 als in 1 Petrus 2:22-25 dient de beschrijving van de knecht in het vierde lied als fundering voor een ethisch appél (Brox 1979:136-140). De gemeente wordt opgeroepen het eigen gedrag af te stemmen op en te modelleren naar de lijdende knecht zoals dat ook gestalte heeft gekregen in het lijden en sterven van Christus. Deze lijn wordt in de patristische periode verder ontwikkeld en uitgebouwd (Sawyer 1996).

We kunnen concluderen dat apostelen en evangelisten de liederen aangaande de knecht des HEREN uiteraard wel gebruiken om het Christusgebeuren te beschrijven en te duiden maar dat er geen sprake is van een exclusief christologisch gebruik. Er zijn echo's van een min of meer letterlijk gebruik, een gebruik dat we ook theologisch in engere zin zouden kunnen noemen. Daarnaast is er sprake van een expliciet ecclesiologisch gebruik.

\subsection{Overwegingen binnen Oude Testament}

Daar voegen zich vanuit het Oude Testament nog enkele overwegingen bij. In de eerste plaats dient de christelijke theologie hermeneutisch te verdisconteren hoe het Oude Testament zelf omgaat met het begrip "knecht". Daarbij valt als eerste op dat het gebruik breed is verankerd en voor meerdere personen en ambtsdragers wordt gebruikt: Abraham (Ps 105:42); Mozes

(Deut 34:5; Num 12:7-8; Joz 1:1, 15; 8:21, 23; 18:7; 1 Kron 6:49; 2 Kron 1:3; 


\section{Van wie zegt de profeet dit?}

24:6; Neh 1:7; 10:29); Jozua, de opvolger van Mozes (Joz 24:29; vgl. Re 2:8); Caleb (Num 12:24); David (2 Sam 7:5-8; 1 Kon 8:66; 11:36; 2 Kon 19:34; 2 Kron 17:4; Ps 18:1); Elia (2 Kon 10:10), and Job (1:8; 42:7); Jesaja (Jes 20:3; 49:5); Jeremia (Jer 7:25-26); Profeten (2 Kon 21:10; Am 3:7); de verlosten (Ps 34:22). Deze opsomming maakt duidelijk dat er geen progressieve heilshistorische reductie te ontdekken is in het gebruik van het begrip "knecht". Deze stelling wordt versterkt doordat ook een niet-Joodse vorst met deze titel wordt aangeduid, te weten Nebukadnessar (Jer 25:9; 27:6; 43:10).

Een volgend belangrijk element in de discussie rond liederen aangaande de knecht des HEREN is de vraag of de knecht naar een individu of een collectivum verwijst. Deze vraag wordt door de teksten zelf opgeroepen. Zo kan Deutero-jesaja aan de ene kant duiden op het volk Israël als geheel (Jes 49:3, 5, 6, 7; zie ook 41:8; 44:1, 2, 21; 45:4; 48:20). Parallel hier aan noemt Jeremia 30:10 Jakob, als aanduiding voor het volk Israël, eveneens "mijn knecht". Degenen die de knecht vooral als een collectivum zien, verstaan het enkelvoudige gebruik als een corporate personality. Daar staat het spreken over de knecht als individu tegenover (Jes 42:1-7; 48:16; 50:4-11). De lijnen naar het Nieuwe Testament worden doorgaans via deze individuele interpretatie getrokken. In een dergelijk dilemma wordt uiteraard ook gezocht naar een constructie die de uitersten harmoniseert. "Deze Knecht is in Gods bedoelingen het nieuwe Israël en daarom vraagt zijn gestalte uiteindelijk om een collectieve verwerkelijking. Het volk van YHWH moet in hem zichtbaar worden" (Beuken 1983:28).

En als derde wijs ik op een eschatologisering van de gestalte van de knecht binnen Deutero-jesaja. Blenkinsopp ziet in 51:4-6 een geeschatologiseerde versie van het eerste lied aangaande de knecht des HEREN (Jes 42:1-9). Dat eerste lied noemt Cyrus nog als middelaar van Gods redding terwijl Jesaja 51 spreekt van Gods directe ingrijpen (Blenkinsopp 2000:77).

\subsection{Resultaten tot nu toe}

Wanneer we het bijbels-theologisch materiaal overzien, moeten we constateren dat een exclusief christologische interpretatie van de knecht des HEREN een reductie van het bijbels-theologisch materiaal betekent en hermeneutische blikvernauwing tot gevolg heeft. Apostelen en evangelisten geven een meer-voudig antwoord op de een-voudige vraag van de eunuch uit Ethiopië. Op basis daarvan moeten we zeggen dat het bijbels-theologisch materiaal zelf vraagt om een meerdimensionaal model waarin recht gedaan wordt aan de diversiteit van de oudtestamentische citaten in het Nieuwe Testament en de veelvormigheid van het Oude Testament. Het gaat om het ontwerpen van een hermeneutische grammatica met het karakter van een 
meervoudig sleutelbos in plaats van een enkelvoudige loper. Een contemporaine hermeneutiek ten dienste van de prediking zal ruimte moeten bieden aan de volgende componenten:

- De knecht verwijst naar het Israël van God als collectivum.

- De roeping en missie van Jezus Christus kan beschreven en geduid worden met woorden, beelden en theologie aangaande de knecht.

- De roeping en de missie van de gemeente uit de volkeren kan vervolgens eveneens beschreven en geduid worden met dezelfde woorden, beelden en theologie.

- Er rust een blijvend eschatologisch tegoed in de woorden van Mozes en de profeten. Ook de liederen aangaande de knecht des HEREN zijn niet uitgeput in Israël, Jezus Christus en de gemeente uit de volkeren. We wachten op het moment dat God alles en in allen zal zijn.

\subsection{Viervoudige schriftzin}

Op zoek naar de betekenissen van een oudtestamentische tekst, treden we een meerdimensionale ruimte binnen. Die ontdekking stond aan de wieg van de ontwikkeling van een eigentijds model van viervoudige schriftzin. In de eerste laag zoeken we naar de (blijvende) betekenis voor Israël, de tweede betekenislaag heeft betrekking op Jezus Christus, de derde laag verwijst naar het leven van de gemeente en de vierde laag heeft een eschatologische dimensie. Dit model dient de spanning tussen de verschillende lagen niet te egaliseren maar vruchtbaar te maken voor de praktijk der prediking.

De kennismaking met de hermeneutiek van de kerkvaders en de Middeleeuwen bood verrassende parallellen (Bos 2004:135-141). Dat model gaf structuur aan eerdere ontdekkingen maar het uiteindelijke resultaat is allerminst een kopie van dat model. Dat is mede omdat de ontmoeting met de theologie na Auschwitz de vulling van het nieuwe model heeft beïnvloed. In alle dynamiek die dit model kenmerkt, blijt de oudtestamentische tekst zelf de ankerplek waar telkens naar verwezen wordt. In alle meervoudigheid wordt zo recht gedaan aan het reformatorische sola Scriptura.

\section{HERMENEUTISCHE EN HOMILETISCHE MOGELIJKHEDEN}

In het patristische model van de viervoudige schriftzin vormt de letterlijk zin van de woorden de eerste betekenislaag waar de andere betekenissen op gebouwd zijn. In de reformatorische traditie is de letterlijke betekenis en de 


\section{Van wie zegt de profeet dit?}

historische achtergrond van de Schrift opnieuw van groot belang geworden. Dat is de ankerplaats voor de uitleg en toepassing van de Schrift in de prediking. Menig concept voor de preekvoorbereiding kent dan ook een belangrijke plaats toe aan het zoeken en vinden van de letterlijke zin van een bijbeltekst. Maar wanneer we proberen te omschrijven wat we precies bedoelen met de letterlijke zin, ontstaat er al snel onduidelijkheid. "There are few more perplexing and yet important problems in the history of biblical interpretation than the issue of defining what is meant by the sensus literalis of a text." (Childs 1977:80; vgl Greene-McCreight 1999).

We moeten dan ook concluderen dat het begrip sensus literalis in de praktijk van de prediking niet goed is te definiëren. De praktijk wijst tevens uit dat deze letterlijke zin aan het risico bloot staat om de blijvende betekenis van het Oude Testament voor Israël buiten de horizon te houden. En ook al zou een voorganger met redelijke zekerheid kunnen vertellen wat de oorspronkelijke schrijver heeft bedoeld, dan nog kan hij ver verwijderd zijn van een in het heden tot klinken brengen van de stem van God (Meijering 2003:10). "Auf der Kanzel soll kein Exeget stehen, der erwägt, ob ein Wort so oder so zu verstehen sei. Das ist notwendige Vorarbeit, die in die Studierstube gehört. Der Gemeinde soll das Ergebnis solch sorgfältiger Arbeit vorgetragen werden" (Barth 1966:107). De zin en betekenis van een tekst ligt niet alleen achter de tekst zodat men om de tekst te verstaan zich zou moeten verdiepen in haar geschiedenis (hetzij literair-historisch of religionsgeschichtlich). De zin en betekenis van de woorden van Mozes en de profeten ligt steeds voor de tekst uit. Voor een eerste betekenislaag moeten we dan ook in een andere richting kijken. Apostelen en evangelisten wijzen de weg: een blijvende betekenis van de woorden voor Israël.

\subsection{Sensus israeliticus}

In het klassieke model van kerkvaders en Middeleeuwen stapt de prediker van de sensus literalis direct over naar de sensus allegoricus, een betekenis die gevuld werd met de christelijke geloofstraditie vanuit dogma en credo. Hedendaagse preken die geborduurd zijn op klassieke hermeneutische modellen hanteren feitelijk dezelfde strategie. In de praktijk van de prediking stappen voorgangers van de oudtestamentische teksten - behandeld in het eerste deel van de preek - doorgaans linea recta over naar het getuigenis aangaande Jezus Christus. Dit getuigenis in de tweede helft van de preek is dan tegelijk het inhoudelijke sluitstuk. In deze gevallen wordt een belangrijke stap overgeslagen, namelijk de (blijvende) betekenis van Mozes en de profeten voor Israël. Ik spreek in dat verband van de sensus israeliticus. Daarmee wordt bedoeld dat de prediker er zelf van bewust dient te zijn en de gemeente er bewust van dient te maken dat deze woorden binnen de context 
van Israël zijn ontstaan, daar hun wortels hebben en derhalve daar niet alleen hun oorspronkelijk zin hebben maar daar een blijvende betekenis houden (Brueggemann 1997, 107-112). Uitleg van het Oude Testament begint met het besef dat de woorden van de $\mathrm{TeNaCh}$ blijvende betekenis hebben voor Israël. Daaruit volgt dat de voorbereiding van een preek naar aanleiding van Mozes en de profeten methodisch ruimte moet maken voor de bezinning op betekenis van deze teksten voor Israël en binnen de Joodse traditie. Ik heb aanzetten gegeven hoe deze dimensie geoperationaliseerd kan worden in het proces van preekvoorbereiding (Bos 2004:199-229).

Daarbij moeten we aantekenen dat het Oude Testament niet over en aangaande Israël spreekt louter omwille van zichzelf. Israël is uitverkoren om een licht te zijn onder de volkeren. In Abraham worden alle geslachten van de aardbodem gezegend (Gen 12:1-3). Ruth en Jona breken de grenzen naar de volkeren nadrukkelijk open. Israël is in die zin nooit "sec" aanwezig in de tekst. Voortdurend wordt Israël aangesproken of wordt er van Israël verhaald met het oog op Gods heilzame voornemen voor de hele volkerenwereld. Vanaf Genesis 1 is de zegen van de HEER bedoelt om effect te hebben voor en uit te vloeien over de hele schepping. Er zit van meet af aan een expansieve dynamiek in het spreken van de HEER tot Israël (Marquardt 1993:455).

Met de sensus israeliticus wordt wel aangegeven dat de woorden van Mozes en de profeten een eigen waarde voor Israël hebben en houden, los van dat wat christenen daar later in horen en lezen. Het kan dan ook niet zo zijn dat de gedachte ontstaat dat er na Christus een rijkere betekenis, ja zelfs de eigenlijke betekenis aan het Oude Testament gegeven kan worden. "Nur eine Predigt, die recht vor Israel redet, kann rechte christliche Bezeugung des gnädigen Gottes bzw. seiner Treue und frohen Botschaft sein" (Stäblein 2004:183).

Als Mozes en de profeten van de trouw van de HEER getuigen, dan is het van belang dat de prediking niet blijft steken in spreken over antiquarische trouw tegenover het oudtestamentische Israël. De trouw van deze God is blijvende trouw, tot op de huidige dag. We hebben het over de eigentijdse Joden "met hun lijden en strijden, hun arrogantie en hun verlangen naar vrede, hun superioriteitsgevoelens en minderwaardigheidscomplexen, hun trouw aan God en zijn beloften (land!) en hun goddeloos ageren en voteren, de al te grove en toch ook weer fijnzinnige dadendrang ... Een in onze ogen miserabele opstelling van regering(en) kan geen veto betekenen tegen Gods aanwezigheid onder hen" (Marquardt 2003:9).

\subsection{Sensus de Christo}

$\mathrm{Na}$ een bezinning op Israël keert de preekvoorbereiding weer terug naar het fundament, te weten de letter van de tekst. In de meerdimensionale betekenisruimte van de tekst kan de christelijke prediking Christus ter sprake 


\section{Van wie zegt de profeet dit?}

brengen aan de hand van woorden, beelden, theologie en metaforen die de oudtestamentische tekst aanbiedt. Marquardt zegt dat Mozes en de profeten de "elementaire deeltjes" leveren voor de christologie (Marquardt 1990, 52, 57). De spelregels voor dat christologisch spreken ontleen ik aan de hermeneutische grammatica zoals we die aantreffen bij apostelen en evangelisten (Bos 2004:234-241). Daarbij neem ik de specifieke exegetische methoden van apostelen en evangelisten niet over maar wel hun theologische Anliegen, namelijk uitgaan van de eenheid van de woorden en werken van de HEER in heden, verleden en toekomst.

Jeremia 17:5-8 kan dienen als illustratie van de wijze waarop het Oude Testament verbonden kan worden met het getuigenis aangaande Jezus Christus.

Zo zegt de HERE: Vervloekt is de man die op een mens vertrouwt en vlees tot zijn arm stelt, wiens hart van de HERE wijkt; hij toch zal zijn als een kale struik in de steppe, die het niet merkt, als er iets goeds komt, maar staat in dorre oorden in de woestijn, een ziltachtig, onbewoond land. Gezegend is de man die op de HERE vertrouwt, wiens betrouwen de HERE is; hij toch zal zijn als een boom, aan het water geplant, die zijn wortels tot aan een beek uitslaat, en het niet merkt, als er hitte komt, maar welks loof groen blijft, die in een jaar van droogte geen zorg heeft en niet nalaat vrucht te dragen.

Deze woorden worden nergens in het Nieuwe Testament geciteerd zodat er geen voorgegeven hermeneutische wegen zijn. Toch kunnen we langs drie wegen dit gedeelte op Christus betrekken. Ten eerste kunnen we de woorden, beelden en motieven uit Jeremia bezien alsof deze tot Jezus zijn gericht, zijn roeping en bestemming tekenen. $\mathrm{Hij}$ is in dat perspectief de rechtvaardige wiens betrouwen de HERE is en die niet nalaat vrucht te dragen.

Een tweede perspectief opent zich door deze woorden in de mond van Jezus te leggen, deze woorden als het ware te zien als preek van Hem. Jezus doet dan een appél op zijn leerlingen en aan de gemeente om zelf goede vruchten voort te brengen.

En vanuit een derde invalshoek kunnen we van Jezus Christus getuigen als de inhoud van de tekst, dat wil zeggen dat we Hem tekenen als de "Boom des levens" die goede vruchten heeft voorgebracht, ons ten goede. Vanuit dat perspectief kan met behulp van woorden, beelden en theologie van dit fragment de soteriologische betekenis van Christus voor gelovigen uit de volkeren aan de orde komen.

In het proces van preekvoorbereiding dient de voorganger te verifiëren of de woorden en de theologie van de oudtestamentische tekst voldoende 
draagkracht hebben om één of meerdere van deze mogelijke verbindingen in de concrete prediking te kunnen aanbrengen. In die exercitie hebben exegese, bijbelse theologie en dogmatiek de rol van controle instrumenten. We zouden ook kunnen zeggen dat de voorganger tijdens het proces van preekvoorbereiding deze disciplines als getuigen hoort ten gunst van de tekst (Lange 1982:30; Van der Laan 1989:117-119).

\subsection{Sensus de gentile}

Met de bagage van de resultaten van eerste en de tweede dimensie van de tekst, keert de prediker opnieuw terug naar de woorden van de tekst. Daar waar de klassieke hermeneutische patronen stoppen, nodigt dit model de prediker uit om voor de derde maal opnieuw te luisteren naar de tekst. Ditmaal om te horen hoe de resonantie van woorden, beelden en theologie van een concrete tekst zich uitstrekt tot de gemeente uit de volkeren. Want de centripetale kracht van Mozes en de profeten strekt zich in en door Jezus Christus uit tot aan de uiteinden der aarde. Het was een verrassende ontdekking om te zien dat apostelen en evangelisten het Oude Testament niet laten eindigen in Jezus Christus. Vrijmoedig citeren ze Mozes en de profeten met het oog op de eigen, actuele situatie van de jonge kerk. Van daar uit is de prediking gemandateerd om de actieradius van Mozes en de profeten eveneens uit te strekken tot aan de uiteinden de aarde.

De nieuwtestamentische schrijvers gaan daarbij verder in de weg van de actualisatie zoals die ook reeds in het Oude Testament voorkomt. In Deuteronomium 5:3 is te horen: "niet met onze vaderen heeft de HEER dit verbond gesloten, maar met ons, zoals wij hier heden allen in leven zijn". Over de eeuwen heen werd het volk keer op keer opgeroepen zelf in de sporen van de exodus te treden. Men ging zelf op die plaats staan.

Wanneer gelovigen uit de volkeren de woorden van Mozes en de profeten openen, sluiten ze zich aan bij deze actualiserende beweging. In en door Jezus Christus zijn wij deelgenoot geworden van de heilzame beweging van Israëls God.

Deze dimensie opent de vensters op het veelkleurige landschap van het Oude Testament. En in dat landschap weerspiegelt op zijn beurt de veelkleurigheid van het gewone leven met z'n hoogten en diepten en de vele vlakten daartussen. Dat betekent dat de prediking naar aanleiding van Mozes en de profeten vele mogelijkheden biedt om dat gewone leven coram Deo, voor Gods aangezicht, ter sprake te brengen.

\subsection{Sensus de vita venturi seaculi}

Nadat de prediker geluisterd heeft naar de tekst in de context van Israël, Jezus Christus en de gemeente, zet hij zich opnieuw tot luisteren. In de tekst ligt nog betekenis te wachten op eschatologische ontsluiting. $\mathrm{Nu}$ is het van 


\section{Van wie zegt de profeet dit?}

belang het begrip eschatologie in dit verband goed te duiden. Het heeft de naam van de leer te zijn over "de laatste dingen". Het gaat dan doorgaans over sterven, de hemel, bij God zijn, de nieuwe hemel en de nieuwe aarde, het nieuwe Jeruzalem. Alles aan gene zijde van leven en dood. Vanaf de tweede helft van de twintigste eeuw is er in kerk en theologie toenemende voorzichtigheid, aarzeling en onzekerheid te bespeuren ten overstaan van dergelijke thema's. Dat had tot gevolg dat deze elementen gaandeweg werden weggeretoucheerd uit de prediking. Voorzichtigheid in het (s)preken over Gods ingrijpen werd gevoed door het zich opdringende bewustzijn van de menselijke mondigheid en verantwoordelijkheid. Die voorzichtigheid intensiveerde zich door de gepostuleerde en ervaren afwezigheid Gods bij rampen. Als God niet ingreep in een concrete situatie in de geschiedenis, waarom zou Hij dan wel willen of kunnen ingrijpen aan het einde der tijden? Deze vraag verdiepte zich ten overstaan van de ervaring van de Holocaust. Dat alles resulteerde in een zekere eschatologische schraalheid in de prediking.

Israël heeft de beloften van de HEER nooit afgeschreven, ondanks haar ervaringen in de geschiedenis. Beloften zijn ook niet uitgeput wanneer deze zich op een bepaald moment in de geschiedenis vullen met concrete woorden of daden. De belofte van rust is bijvoorbeeld niet volledig vervuld of uitgediept met de intocht in het beloofde land, Kanaän. Er bleef in de belofte als het ware nog iets "open staan". Zoals er een restant open kan blijven bij het niet geheel verbruiken van een tegoedbon of telefoonkaart.

Nu spreekt en getuigt het Oude Testament breedvoerig over de toekomst, maar niet (alleen) op de wijze zoals dat vorm heeft gekregen in de christelijke geloofsleer. In het Oude Testament gaat het over "het naar ons toe komen" van de HEER die met mens en wereld op weg is naar de realisering van Zijn heil. Spreken en getuigen van de toekomst is in het Oude Testament steeds spreken en getuigen van deze komende God. Dat houdt in dat de HEER zelf het midden vormt van de beloften. Hij is zowel de inhoud van de beloften als Degene die garant staat voor de vervulling. Dé belofte is dan ook vervat in Zijn Naam: Ik zal zijn, die Ik zijn zal (Exodus 3). Op basis van deze belijdenis is er een veelvormig spreken over de toekomst en Gods betrokkenheid daarbij. Deze veelvormigheid is niet zo makkelijk te systematiseren. Binnen het Oude Testament is echter wel een zekere gelaagdheid waar te nemen met betrekking tot het spreken over de toekomst en Gods bemoeienis daarmee (Vriezen:1977:493-496; Vriezen 1978:122-128). Zo zijn de volgende elementen te onderscheiden:

- Tastbaar heil na de crisis

- Crisis als gericht 
- Een nieuw, binnen-historisch, perspectief na de crisis

- Alles nieuw aan gene zijde van deze geschiedenis

[PUNT] De dimensies van het eschatologische spreken zijn geen stations op een eenrichtingsweg. Er is een wederkerige beweging tussen de stations. Elk van deze onderdelen biedt de contemporaine prediking mogelijkheden tot hoorder-nabije prediking (Bos 2004:301-321).

\section{EEN MEER-VOUDIG ANTWOORD}

Dit eigentijdse model van viervoudige schriftzin is bruikbaar in de praktijk van de prediking. Het lost de spanning tussen wetenschappelijke reflectie en getuigen van Christus niet op maar maakt die spanning vruchtbaar voor beiden. Dit model biedt een sleutelbos voor het openen van de binnenkant van oudtestamentische teksten en blijft de letter van de tekst als ankerplek houden. Het model doet tevens recht aan de dynamiek en de veelkleurigheid van het getuigenis van Mozes en de profeten die op zijn beurt weer spiegel is van de veelkleurige en soms ook weerbarstige existentiële ervaringen. Dit model plaatst een prediker van meet af aan op een weg die heen en weer gaat tussen de tekst aan de ene kant en Israël, Jezus Christus, de gemeente en het eschaton aan de andere kant. Daarmee is methodisch verweer geboden tegen hermeneutisch eenrichtingsverkeer. Deze dynamische wederkerigheid kan de preekpraktijk inspirerende impulsen geven.

\section{Literatuurverwijzing}

Allen, R J 1998. Interpreting the gospel: An introduction to preaching. St Louis, MO:

Chalice Press.

Barth, K 1966. Homiletik: Wesen und Vorbereitung der Predigt. Zürich: EVZ-Verlag.

Barth, K 1980. Einführung in die evangelische Theologie. Gütersloh: Gütersloher Verlag. (GTS 191.)

Blenkinsopp, J 2000. Isaiah 40-55. New York: Doubleday. (The Anchor Bible, 19a.)

Bohren, R 1986. Predigtlehre. 5.Aufl. München: Kaiser.

Bos, R 2004. Wij hebben gehoord dat God met $u$ is: Preken vanuit het Oude

Testament. Zoetermeer: Boekencentrum.

Brox, N 1979. Der Erste Petrusbrief. Neukirchen: Neukircher Verlag. (EKK XXI.)

Brueggemann, W 1997. Theology of the Old Testament: Testimony, dispute, advocacy. Minneapolis, MN: Fortress Press.

Büttner, M 2002. Das Alte Testament als erster Teil der christlichen Bibel: Zur Frage nach theogischer Auslegung und "Mitte" im Kontext der Theologie Karl Barths, München: Kaiser.

Buttrick, D 1987. Homiletic: Moves and structures, London: SCM.

Childs, B S 1977. The sensus literalis of scripture: An ancient and modern problem, in Donner 1977:80-93.

Davis, H G 1958. Design for preaching, Philadelphia, PA: Fortress Press. 


\section{Van wie zegt de profeet dit?}

Dingemans, G D J 1991. Als hoorder onder de hoorders ...: Een hermeneutische homiletiek. Kampen: Kok.

Dohmen, C \& Stemberger, G 1996. Hermeneutik der Jüdischen Bibel und Alten Testaments. Stuttgart: Kohlhammer. (Kohlhammer Studienbücher Bd. 1, 2.)

Donner, H (Hrsg) 1977. Beiträge alttestamentlicher Theologie: Festschrift für Walther Zimmerli zum 70. Geburtstag. Göttingen: Vandenhoeck und Ruprecht.

Dunn, J D G 1988. Romans 9-16. Waco: Word Books Publisher. (Word Biblical Commentary VIm. 38B.)

Engemann, W 2002. Einführung in die Homiletik. Tübingen: Francke. (UniTaschenbücher 2128.)

Grässer, E 1990. An die Hebräer (Hebr 1-6). Neukirchen: Neukirchener Verlag. (EKK $\mathrm{XVII} / 1$.)

Greene-McCreight, K E 1999. Ad Litteram: How Augustine, Calvin, and Barth read the "Plain Sense" of Genesis 1-3. New York: Lang

Gunneweg, A H J 1977. Vom Verstehen des Alten Testaments. Göttingen: Vandenhoeck und Ruprecht.

Gunneweg, A H J 1983. Sola Scriptura. Göttingen: Vandenhoeck \& Ruprecht.

Gunneweg, A H J 1983a. Über die Prädikabilität alttestamentlicher Texte, in Gunneweg 1983:159-183.

Guthrie, D 1981. New Testament Theology. Leicester: Inter-Varsity Press.

Hirschler, H 1988. Biblisch predigen, 2de druk. Hannover: Lutherisches Verlagshaus. Hoekstra, T 1975. Gereformeerde Homiletiek, 3de druk. Amsterdam: Ton Bolland. Jong, C de 1984. Zondag na Kerst, in Van der Laan 1984:239-246.

Jong, P L de 1995. Preek naar aanleiding van Jesaja 42:1-6. Hilversum: IKON (IKON R 73.)

Klein, G L et al 1992. Reclaiming the prophetic mantle: Preaching the Old Testament. Nashville, TN: Broadman Press.

Koole, J L 1985. Jesaja II/1. Kampen: Kok. (Commentaar op het Oude Testament.)

Lindijer, C H 1979. Handelingen van de apostelen, II. Nijkerk: Callenbach. (De prediking van Nieuwe Testament.)

Lange, E 1982. Predigen als Beruf: Aufsätze zur Homiletik, Liturgie und Pfarramt. München: Kreuz-Verlag.

Long, T G 1989. The witness of preaching. Westminster: Westminster Press.

Marquardt, F W 1993, Was dürfen wir hoffen, wenn wir hoffen dürften? Eine Eschatologie, Bd. 1. Gütersloh: Gütersloher Verlagshaus.

Marquardt, F W 1998. Das christliche Bekenntnis zu Jesus dem Juden: Eine Christologie, Bd. 2. Gütersloh: Gütersloher Verlagshaus.

Marquardt, F W 2003. Bij de slip van zijn kleed ...: Een christelijke theologie na Auschwitz. Kampen: Ten Have.

Meijering E P 2003. Als de uitleg maar goed is: Hoe vroege christenen de bijbel gebruikte. Zoetermeer: Boekencentrum.

Müller, H M 1996. Homiletik: Eine evangelische Predigtlehre. Berlin: De Gruyter.

Müller, K 1994. Homiletik: Ein Handbuch für kritische Zeiten. Regensburg: Pustet.

Oeming, M 1985. Gesamtbiblische Theologien der Gegenwart: Das Verhältnis von

AT und NT in der hermeutichen Diskussion seit Gerhard von Rad. Stuttgart:

Kohlhammer.

Preuß H D (Hrsg) 1978. Eschatologie im Alten Testament. Darmstadt:

Wissenschaftliche Buchgeselschaft. 
Preuß H D 1984. Das Alte Testament in christlicher Predigt. Stuttgart: Kohlhammer Rendtorff, R et al 1961. Studien zur Theologie alttestamentlicher Überlieferungen: Festschrift für Gerhard von Rad. Neukirchen: Neukirchener Verlag.

Rössler, D 1961. Die Predigt über alttestamentliche Texte, in Rendtorff et al 1961.

Sawyer J F A 1996. The Fifth Gospel: Isaiah in the history of Christianity. Cambridge: Cambridge University Press.

Stäblein, C 2004. Predigen nach dem Holocaust: das jüdische Gegenüber in der evangelischen Predigtlehre nach 1945. Göttingen: Vandenhoeck und Ruprecht.

Schütz, W 1981. Probleme der Predigt. Göttingen: Vandenhoeck und Ruprecht. Theißen, G 1994. Zeichensprache des Glaubens. Gütersloh: Gütersloher Verlag.

Van der Laan, J H (red) 1984. Woord in beweging 1 (Advent tot Epifanie I). Kampen: Kok.

Van der Laan, J H 1989. Ernst Lange en de prediking: Een inleiding in zijn homiletische theorie. Kampen: Kok.

Van Eck, J 2003. Handelingen: De wereld in het geding. Kampen: Kok.

Vos, C J A 1995. Die blye tyding: Homiletiek uit 'n hermeneuties-kommunikatiewe perspektief. Pretoria: Raad vir Geesteswetenskaplike Navorsing.

Vriezen T C 1977. Hoofdlijnen der theologie van het Oude Testament, 5de druk. Wageningen: Veenman.

Vriezen T C 1978. Prophetie und Eschatologie, in Preuß 1978:88-128.

Watts J D W 1987. Isaiah 34-66. Waco: Word Books. (Word Biblical Commentary VIm. 25.)

Zerfaß, R 1992. Grundkurs Predigt 2: Textpredigt. Düsseldorf: Patmos. 